\title{
Landscape Metrics and Indices: An Overview of Their Use in Landscape Research
}

\author{
Evelin Uuemaa \\ Department of Geography, Institute of Ecology and Earth Sciences, University of Tartu, \\ 46 Vanemuise St., Tartu, Estonia, 51014 \\ email: kevelyn@ut.ee \\ Marc Antrop \\ Department of Geography, University of Ghent, Krijgslaan 281 S8, 9000 Gent, Belgium \\ email: Marc.Antrop@UGent.be \\ Jüri Roosaare \\ University of Tartu (see above) \\ email: juri.roosaare@ut.ee \\ Riho Marja \\ University of Tartu (see above) \\ email: riho.marja@ut.ee \\ Ülo Mander \\ University of Tartu (see above) \\ email: ulo.mander@ut.ee

\section{Living Reviews in Landscape Research \\ ISSN 1863-7329}

Accepted on 1 March 2009

Published on 17 March 2009

\begin{abstract}
The aim of this overview paper is to analyze the use of various landscape metrics and landscape indices for the characterization of landscape structure and various processes at both landscape and ecosystem level. We analyzed the appearance of the terms landscape metrics/indexes/indices in combination with seven main categories in the field of landscape ecology [1) use/selection and misuse of metrics, 2) biodiversity and habitat analysis; 3) water quality; 4) evaluation of the landscape pattern and its change; 5) urban landscape pattern, road network; 6) aesthetics of landscape; 7) management, planning and monitoring] in the titles, abstracts and/or key words of research papers published in international peer-reviewed scientific journals indexed by the Institute of Science Information (ISI) Web of Science (WoS) from 1994 to October 2008. Most of the landscape metrics and indices are used concerning biodiversity and habitat analysis, and also the evaluation of landscape pattern and its change (up to 25 articles per year). There are only a few articles on the relationships of landscape metrics/indices/indexes to social aspects and landscape perception.
\end{abstract}

Keywords: Biodiversity; FRAGSTATS, Landscape aesthetics, Landscape ecology, Landscape pattern; Landscape planning

This review is licensed under a Creative Commons Attribution-Non-Commercial-NoDerivs 3.0 Germany License. http://creativecommons . org/licenses/by-nc-nd/3.0/de/ 


\section{Imprint / Terms of Use}

Living Reviews in Landscape Research is a peer reviewed open access journal published by the Leibniz Centre for Agricultural Landscape Research (ZALF), Eberswalder Straße 84, 15374 Müncheberg, Germany. ISSN 1863-7329.

This review is licensed under a Creative Commons Attribution-Non-Commercial-NoDerivs 3.0 Germany License: http://creativecommons.org/licenses/by-nc-nd/3.0/de/

Because a Living Reviews article can evolve over time, we recommend to cite the article as follows:

Evelin Uuemaa, Marc Antrop, Jüri Roosaare, Riho Marja and Ülo Mander, "Landscape Metrics and Indices: An Overview of Their Use in Landscape Research",

Living Rev. Landscape Res., 3, (2009), 1. [Online Article]: cited [<date $>$ ], http://www.livingreviews.org/lrlr-2009-1

The date given as $<$ date $>$ then uniquely identifies the version of the article you are referring to.

\section{Article Revisions}

Living Reviews supports two different ways to keep its articles up-to-date:

Fast-track revision A fast-track revision provides the author with the opportunity to add short notices of current research results, trends and developments, or important publications to the article. A fast-track revision is refereed by the responsible subject editor. If an article has undergone a fast-track revision, a summary of changes will be listed here.

Major update A major update will include substantial changes and additions and is subject to full external refereeing. It is published with a new publication number.

For detailed documentation of an article's evolution, please refer always to the history document of the article's online version at http://www. livingreviews.org/lrlr-2009-1. 


\section{Contents}

1 Introduction $\quad 5$

2 Methods $\quad 5$

3 Results and Discussion $\quad 6$

3.1 "Landscape metrics" vs "landscape indices" . . . . . . . . . . . . . . . . . . . . . . . . . . . . . .

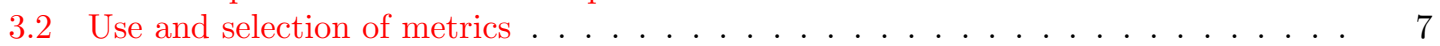

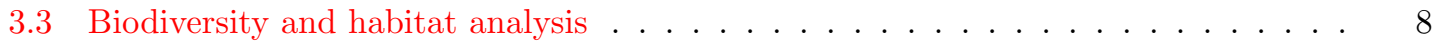

3.4 Estimating water quality . . . . . . . . . . . . . . . . . . . . . . . . 11

3.5 Evaluation of landscape pattern and changes therein . . . . . . . . . . . . 11

3.6 Urban landscape pattern, road network . . . . . . . . . . . . . . . . . 13

3.7 Landscape aesthetics . . . . . . . . . . . . . . . . . . . . . . . . 14

3.8 Management and planning . . . . . . . . . . . . . . . . . . 15

4 Conclusions $\quad 17$

5 Acknowledgements $\quad 17$

$\begin{array}{lr}\text { References } & 18\end{array}$

\section{List of Tables}

1 Correlations between various landscape metrics and biological variables indicating biodiversity and habitat features. . . . . . . . . . . . . . . . . . 9

2 Correlation between various landscape metrics and water quality parameters. . . . 12

3 Correlation between various landscape metrics and parameters characterizing land-

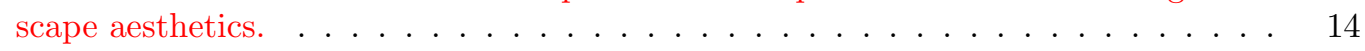





\section{Introduction}

The quantification of spatial heterogeneity is necessary to elucidate relationships between ecological processes and spatial patterns (Turner, 1990; Turner et al., 2003). Therefore the measurement, analysis and interpretation of spatial patterns receive much attention in landscape ecology (HainesYoung and Chopping, 1996). A great variety of metrics for landscape composition (e.g., the number and amount of different habitat types) and configuration (the spatial arrangement of those classes) were developed for categorical data. Software packages are widely used (e.g., FRAGSTATS, see McGarigal and Marks, 1995; McGarigal et al., 2002), and many metrics have also been integrated into existing geographic information system (GIS) software (e.g., Patch Analyst in ArcView; and module Pattern in IDRISI).

Although spatial pattern analysis should be considered to be a tool rather than a goal in and of itself, and the objectives or questions driving any analysis must include the qualities of the pattern to be represented and why, there are many examples in the literature when this has not been correctly followed ( $\mathrm{Li}$ and $\mathrm{Wu}, 2004)$. Several issues associated with the interpretation of landscape metrics are widely used by practitioners (Gustafson, 1998; Haines-Young and Chopping, 1996; Li and Wu, 2004; Turner et al., 2003). Many metrics are sensitive to changes in the spatial resolution (grain size) of the data or the area (extent) of the landscape (Wickham and Riitters, 1995), and numerous correlations occur among landscape indices (Riitters et al., 1995; Cain et al., 1997). The downscaling and upscaling of landscape metrics as functional and structural landscape indicators at different scales still remains a challenge (Mander et al., 2005).

On the other hand, the common usage of the term "landscape metrics" mostly refers to indices developed for categorical map patterns (McGarigal et al., 2002), but it is sometimes also used for topographic measures (Iampietro et al., 2005; Vivoni et al., 2005) that characterize landscape, or it may also just refer to some combination of several characteristics that are important to a particular species (Schils, 2006; Fernández et al., 2007).

The main aim of this paper is to give an overview of the development and state of the art of the applications for landscape metrics, one of the classical landscape ecological tools, and study objects that help us better understand the relationships between landscape pattern and processes.

\section{Methods}

We analyzed papers published in international peer-reviewed journals that are indexed by the Institute of Science Information (ISI) Web of Science (WoS) from 1994 to October 2008. The terms "landscape metrics", "landscape indexes" and "landscape indices" were searched as both separate items and in combination with the following terms:

"biodiversity", "habitat", "urban landscape", "road network", "water quality", "watershed(s)", "catchment(s)", "landscape pattern", "landscape structure", "Fragstats", "land use", "land use change", "landscape aesthetics" and "aesthetics of landscape", "landscape planning", "landscape management".

The appearance of these terms and combinations thereof in the titles, abstracts and/or key words of papers was taken into account. The overlapping issues (if the terms or combinations appeared in the same paper) were not double-counted. 


\section{Results and Discussion}

There are 331 articles for the term "landscape metrics", 131 articles for the term "landscape indices", and 17 for "landscape indexes" in the ISI Web of Science literature database (October 14, 2008). In fact, some of the articles overlapped, and a few articles were added by using the singular form of the two terms. We therefore eventually reviewed 337 articles for the term "landscape metrics", and 141 articles for the term "landscape indices" and "landscape indexes".

\section{1 "Landscape metrics" vs "landscape indices"}

The term "landscape metrics" appears more frequently, but there are no definite rules or traditions as to when one or the other term is used. It seems that the term "landscape metrics" is used more often only for metrics calculated by Fragstats or by some of its developments in other programs (FRAG*ARC, Fragstats for ArcView, Patch Analyst etc). The term "landscape indices" is more frequently used in a broader sense, i.e., metrics have similar or the same formulae as in Fragstats but are named differently. Also, in terms of the timeline of their use (Figure 1), it can be seen that the term "landscape indices" was more often used in the 1990s, and now the term "landscape metrics" is prevalent. From here on we will only use the term "landscape metrics".

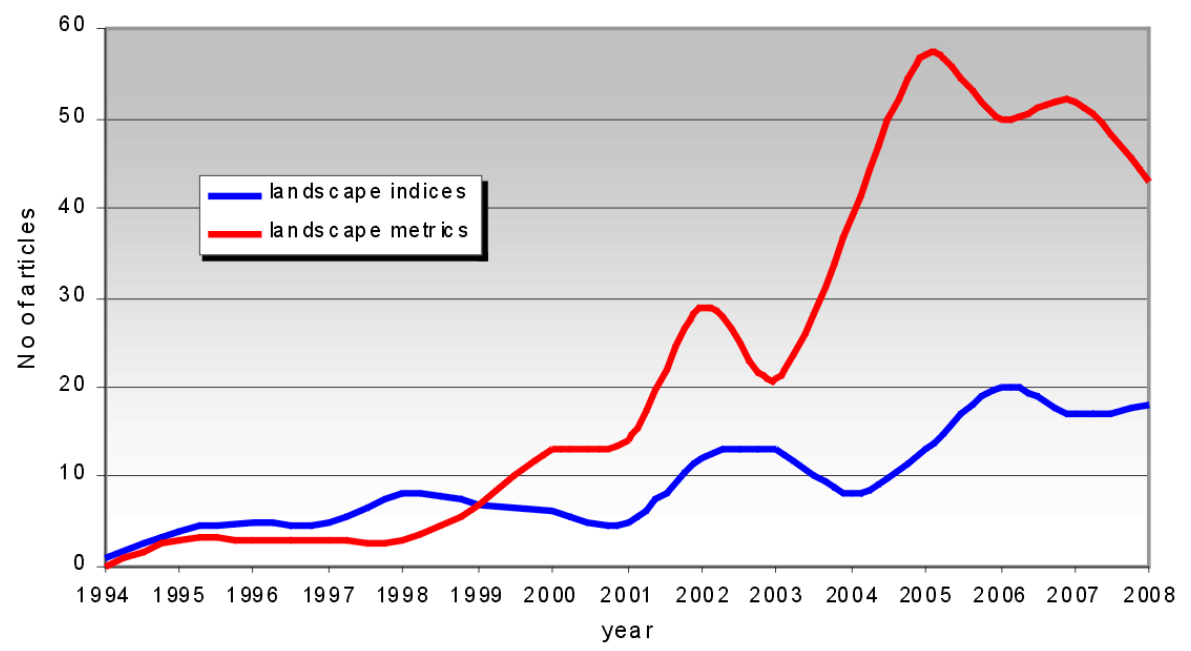

Figure 1: The use of the terms "landscape metrics" and "landscape indices" in titles, abstracts and/or key words of international peer-reviewed scientific papers. The analysis has been performed on the basis of journal papers indexed by the ISI Web of Science from 1994 to October 2008.

The usage of landscape metrics is very broad, and can be grouped into seven general categories: a) use and misuse/ selection of metrics; b) biodiversity and habitat analysis; c) estimating water quality; d) evaluation of landscape pattern and changes therein; e) urban landscape pattern, road network; f) aesthetics of landscape; g) management, planning and monitoring. Category e) is actually more like a subcategory of $\mathrm{d}$ ), but since the human impact on landscapes is so important and has been very widely explored, we decided to analyze it separately. Most of the studies published from 1994-2008 are on biodiversity and habitat analysis, and the evaluation of landscape pattern and changes therein (up to 25 articles per year; Figure 2). There are up to 15 articles per year about the use and misuse / selection of metrics. The number of articles published each year has generally increased since 1994, but for example articles published on the relations between landscape aesthetics relations and landscape metrics has been surprisingly low.

Living Reviews in Landscape Research

http://www. livingreviews.org/lrlr-2009-1 


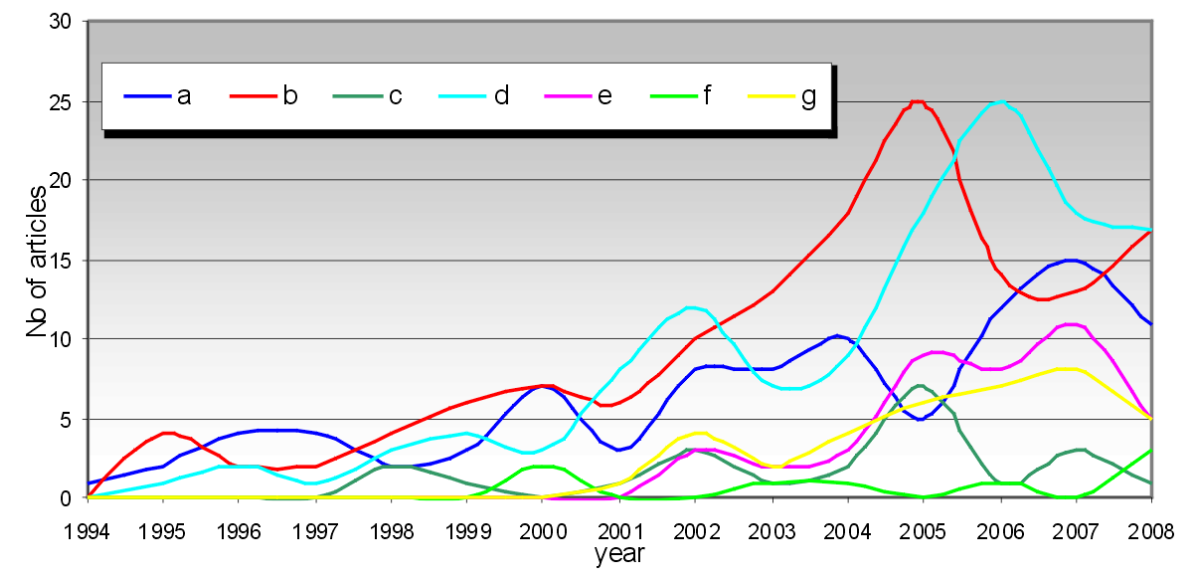

Figure 2: The use of the following terms and their combinations in titles, abstracts and/or key words of international peer-reviewed scientific papers: a) use and misuse/selection of metrics; b) biodiversity and habitat analysis; c) estimating water quality; d) evaluation of landscape pattern and changes therein; e) urban landscape pattern, road network; f) landscape aesthetics; g) management, planning and monitoring. The analysis has been performed on the basis of journal papers indexed by the ISI Web of Science from 1994 to October 2008.

\subsection{Use and selection of metrics}

Many of the articles have been written on the use and misuse and selection principles of landscape metrics. As there are literally hundreds of landscape metrics, many of the landscape metrics are correlated to each other, which makes interpretation more difficult. Riitters et al. (1995) found that the first six factors explained about $87 \%$ of the variation in the 26 landscape metrics, and these factors were interpreted as composite measures of average patch compaction, overall image texture, average patch shape, patch perimeter-area scaling, the number of attribute classes, and large-patch density-area scaling. Cushman et al. (2008) performed principal component analysis (PCA) and cluster analysis to identify independent components of landscape structure and group them, and found that there were eight universal and consistent combinations of Fragstats metrics that universally describe the major attributes of landscape structure at the landscape level. Botequilha Leitão and Ahern (2002) even proposed a core set of metrics that are most useful and relevant for landscape planning and Schindler et al. (2008) proposed set of metrics for establishing a landscape monitoring program, to detect the local drivers of biodiversity in Mediterranean area. The interpretation of some of the landscape metrics is also complicated because their behaviour has not yet been evaluated (McGarigal et al., 2002). In that field, neutral landscapes are useful (see for example Neel et al., 2004; Li et al., 2005a).

Another important issue is that the results of spatial data analysis depend on data aggregation methods and the zoning scheme. Its general formulation is known as the modifiable areal unit problem (MAUP), created by (Openshaw and Taylor, 1981). MAUP in the context of landscape ecology consists of three related aspects: how the grain size, zoning and areal extent of investigation influence results, and how to determine their optimal values for each particular case. The dependence of landscape metrics on grain size is studied by (Wickham and Riitters, 1995; Uuemaa et al., 2005; Buyantuyev and Wu, 2007). Wickham et al. (1997); Huang et al. (2006); Langford et al. (2006) have studied the influence of map classification, and Wu et al. (2002) and Wu (2004) have studied the extent of the study area on the value of landscape metrics.

Although there are already hundreds of landscape metrics, several researchers have proposed 
new landscape metrics. Jaeger (2000) proposed a degree of landscape division $(D)$, splitting index $(S)$, and effective mesh size $(m)$, which characterize the anthropogenic penetration of landscapes from a geometric point of view and are calculated from the distribution function of the remaining patch sizes. (He et al., 2000) proposed new metric (aggregation index- $A I$ ) for measuring aggregation in landscape pattern. $A I$ is class-based, and contrary to contagion, it is independent of composition. All of these metrics are now also available in Fragstats. The fact that researchers are still working out new metrics indicates the need for measuring new aspects of landscape pattern but also researchers' aspiration to overcome the collinearity in Fragstats metrics.

\subsection{Biodiversity and habitat analysis}

The relationship between landscape metrics and bird species richness and their habitat preferences has been studied most extensively. There are many studies that have been performed on the relationships between landscape parameters and specific species - owls (Carey et al., 1992; Ribe et al., 1998), sparrows (Perkins and Conner, 2003), turkeys (Chamberlain et al., 2000; Miller and Conner, 2007), woodpeckers (Wigley et al., 1999), bobwhites (Guthery et al., 2001; Twedt et al., 2007), grouses (Fearer and Stauffer, 2003), pheasants (Clark et al., 1999) and ducks (Stephens et al., 2005). Different studies have shown that most bird species responded more strongly to the composition of land-cover classes than to the configuration of the landscape (Table 1). Of landscape configuration metrics, patch size has given the most important relationships with bird species richness, i.e., fragmentation plays an important role for birds.

Landscape metrics have been used to determine the landscape preferences of raccoons (Henner et al., 2004), gray wolves (Mladenoff et al., 1995), wild hogs (Gaines et al., 2005); moose (Maier et al., 2005), deer (Foster et al., 1997; Finder et al., 1999; Kie et al., 2002), black bears (Kindall and Van Manen, 2007), ocelots (Jackson et al., 2005), elk (Stubblefield et al., 2006), possums (Eyre and Buck, 2005) and bats (Limpert et al., 2007). Different species provide different correlations with landscape metrics depending on their landscape preferences, i.e., large compact patches are preferred by wild hogs (Gaines et al., 2005), moose (Maier et al., 2005), deer (Table 1; Foster et al., 1997; Plante et al., 2004) and possums (Eyre and Buck, 2005), while ocelots (Jackson et al., 2005) and gliders (Table 1; McAlpine and Eyre, 2002) preferred areas that had a greater degree of fragmentation (i.e., a larger number of patches of smaller size, and with more edge).

Several studies have even shown the significance of landscape pattern (measured by landscape metrics) on frog populations (Table 1; Knutson et al., 1999; Pellet et al., 2004) and on insect population levels (Radeloff et al., 2000; French et al., 2004; Roschewitz et al., 2005). The structure of the landscape may be important to explain and understand the epidemiology associated with insects (Graham et al., 2004). Overgaard et al. (2003) studied the influence of landscape structure on Anopheline mosquito density, and based on their results suggested that if landscape management were to be used for malaria control, the large-scale reduction and fragmentation of forest cover would be needed in the case of northern Thailand. The risk of transmission of Lyme disease has been found to be influenced by landscape structure and the spatial arrangement of land cover types (Turner, 1989). Brownstein et al. (2005) performed an analysis of the landscape pattern of forest patches using satellite imagery, and calculated landscape indices revealed a positive link between fragmentation and both tick density and the prevalence of infection in ticks. Yang et al. (2008) investigated ecological variability related to the distribution of Oncomelania hupensis, the snail intermediate host of Schistosoma japonicum, and found that the reduction of the heterogeneity of the landscape could reduce snail density.

It is known that habitats composed of spatially heterogeneous abiotic conditions provide a great diversity of potentially suitable niches for plant species. The scientific premises of landscape ecology suggest that, at a higher spatial level, the composition and structure of the landscape mosaic also influences biotic processes and hence species richness (Honnay et al., 2003). There are several

Living Reviews in Landscape Research

http://www. livingreviews.org/lrlr-2009-1 
studies on the determining of relationships between landscape structure (estimated with landscape metrics) and plant diversity (Table 1; Moser et al., 2002; Burton and Samuelson, 2008; HernándezStefanoni and Dupuy, 2008). A growing number of ecological studies have focused on alien plants' invasive processes in order to predict further invasions and associated potentially negative effects. The introduction of alien plants or plant species new to an area due to human activity and their spread and establishment is thought to cause a decline in the diversity of native species (Williamson, 1999). Deutschewitz et al. (2003) found that the species richness of native and alien plants increases with moderate levels of natural and/or anthropogenic disturbances, coupled with high levels of habitat and structural heterogeneity in urban, riverine, and small-scale rural ecosystems. Kumar et al. (2006) found that both native and non-native plant species richness were positively correlated with edge density, Simpson's diversity index and the interspersion/juxtaposition index, and were negatively correlated with mean patch size (Table 1). Landscape metrics of watersheds have also proven to be useful for the identification of estuarine benthic conditions and degraded bottom communities (Hale et al., 2004).

Table 1: Correlations between various landscape metrics and biological variables indicating biodiversity and habitat features. Significance: ${ }^{*} \mathrm{p}<0.05,{ }^{* *} \mathrm{p}<0.01,{ }^{* * *} \mathrm{p}<0.001,{ }^{* * * *} \mathrm{p}<0.0001$.

\begin{tabular}{|c|c|c|c|c|}
\hline Taxa & Landscape metrics & $\begin{array}{l}\text { Dependent vari- } \\
\text { ables }\end{array}$ & Pearson $\mathbf{r}$ & References \\
\hline Amphibia & $\begin{array}{l}\text { Density of urban land- } \\
\text { cover in a buffer of } \\
30 \mathrm{~m} \text { around the pond }\end{array}$ & $\begin{array}{l}\text { calling sites selection } \\
\text { by males of tree frog } \\
\text { (Hyla arborea) }\end{array}$ & $-0.23^{* * *}$ & Pellet et al. (2004) \\
\hline \multirow[t]{13}{*}{ Mammals } & $\log _{10}$ forest patch area & $\begin{array}{l}\text { carnivores species rich- } \\
\text { ness }\end{array}$ & $0.69^{* * *}$ & $\begin{array}{l}\text { Michalski and Peres } \\
(2005)\end{array}$ \\
\hline & & $\begin{array}{l}\text { primates species rich- } \\
\text { ness }\end{array}$ & $0.65^{* * *}$ & \\
\hline & $\begin{array}{l}\text { Mean woods patch size } \\
(\log )\end{array}$ & $\begin{array}{l}\text { deer vulnerability to } \\
\text { harvest (log) }\end{array}$ & $-0.75^{* * * *}$ & Foster et al. (1997) \\
\hline & Proximity index (log) & & $-0.76^{* * * *}$ & Foster et al. (1997) \\
\hline & $\begin{array}{l}\text { mean woods patch } \\
\text { shape (log) }\end{array}$ & & $-0.7^{* * * *}$ & Foster et al. (1997) \\
\hline & $\begin{array}{l}\text { Mean nearest neigh- } \\
\text { bour distance }\end{array}$ & & $0.76^{* * * *}$ & Foster et al. (1997) \\
\hline & Number of patches & Deer density & $0.43^{*}$ & Plante et al. (2004) \\
\hline & Edge density & & $0.37^{* * *}$ & Plante et al. (2004) \\
\hline & Mean Patch Size & $\begin{array}{l}\text { Count of the Yellow- } \\
\text { bellied Glider (Petau- } \\
\text { rus australis) }\end{array}$ & $-0.25^{*}$ & $\begin{array}{l}\text { McAlpine and Eyre } \\
(2002)\end{array}$ \\
\hline & Edge density & & $0.29 *$ & $\begin{array}{l}\text { McAlpine and Eyre } \\
(2002)\end{array}$ \\
\hline & $\begin{array}{l}\text { Contrast weighted } \\
\text { edge density }\end{array}$ & & $0.28^{*}$ & $\begin{array}{l}\text { McAlpine and Eyre } \\
(2002)\end{array}$ \\
\hline & Largest patch index & $\begin{array}{l}\text { Diversity of exudivore } \\
\text { species }\end{array}$ & $-0.26^{*}$ & $\begin{array}{l}\text { McAlpine and Eyre } \\
(2002)\end{array}$ \\
\hline & $\begin{array}{l}\text { Shannon's evenness } \\
\text { index }\end{array}$ & & $0.33^{*}$ & $\begin{array}{l}\text { McAlpine and Eyre } \\
(2002)\end{array}$ \\
\hline
\end{tabular}


Table 1 - Continued

\begin{tabular}{|c|c|c|c|c|}
\hline Taxa & Landscape metrics & $\begin{array}{l}\text { Dependent vari- } \\
\text { ables }\end{array}$ & Pearson $r$ & References \\
\hline & Contagion & & $-0.33^{*}$ & $\begin{array}{l}\text { McAlpine and Eyre } \\
(2002)\end{array}$ \\
\hline \multirow[t]{5}{*}{ Birds } & Agricultural land (ha) & $\begin{array}{l}\text { Number of hooded } \\
\text { crane }\end{array}$ & $0.79^{* *}$ & Liu et al. (2003) \\
\hline & Proportion forest & $\begin{array}{l}\text { Abundance of female } \\
\text { cowbirds }\end{array}$ & $0.62^{* *}$ & Fauth et al. (2000) \\
\hline & Proportion forest & $\begin{array}{l}\text { Abundance of indigo } \\
\text { buntings }\end{array}$ & $-0.77^{* *}$ & Fauth et al. (2000) \\
\hline & Proximity index & & $-0.35^{* *}$ & Fauth et al. (2000) \\
\hline & Edge density & $\begin{array}{l}\text { Abundance of wood } \\
\text { thrushes }\end{array}$ & $0.37 * *$ & Fauth et al. (2000) \\
\hline \multirow[t]{8}{*}{ Insects } & $\begin{array}{l}\text { Total area of host } \\
\text { patches }\end{array}$ & $\begin{array}{l}\text { Mean abundance of } \\
\text { (Delphacodes kuscheli) }\end{array}$ & $0.79^{* * *}$ & Grilli (2008) \\
\hline & $\begin{array}{l}\text { Mean proximity index } \\
\text { (host patches) }\end{array}$ & & $0.96^{* * *}$ & Grilli (2008) \\
\hline & Class area (maize) & $\begin{array}{l}\text { Total number of west- } \\
\text { ern corn rootworm }\end{array}$ & $0.91^{*}$ & Beckler et al. (2004) \\
\hline & $\begin{array}{l}\text { Number of patches } \\
\text { (maize) }\end{array}$ & & $0.9^{*}$ & Beckler et al. (2004) \\
\hline & $\begin{array}{l}\text { Proximity (maize } \\
\text { patches) }\end{array}$ & & $0.99^{* *}$ & Beckler et al. (2004) \\
\hline & Edge density & $\begin{array}{l}\text { Mean jack pine bud- } \\
\text { worm (Choristoneura } \\
\text { pinus pinus) } \\
\text { population levels }\end{array}$ & $0.26^{*}$ & Radeloff et al. (2000) \\
\hline & & $\begin{array}{l}\text { Corrected mean } \\
\text { perimeter area ratio }\end{array}$ & $0.34^{*}$ & Radeloff et al. (2000) \\
\hline & $\begin{array}{l}\text { Modified Simpson's } \\
\text { diversity index }\end{array}$ & $\begin{array}{l}\text { Anopheline species } \\
\text { diversity (Shannon-- } \\
\text { Weaver diversity in- } \\
\text { dex) }\end{array}$ & $-0.74^{*}$ & $\begin{array}{l}\text { Overgaard et al. } \\
(2003)\end{array}$ \\
\hline \multirow[t]{6}{*}{ Plants } & Forest cover $(\%)$ & $\begin{array}{l}\text { Riparian woody plant } \\
\text { species richness }\end{array}$ & $0.78^{* *}$ & $\begin{array}{l}\text { Burton and Samuelson } \\
\text { (2008) }\end{array}$ \\
\hline & $\begin{array}{l}\text { Shannon's diversity } \\
\text { index }\end{array}$ & & $-0.74^{* *}$ & $\begin{array}{l}\text { Burton and Samuelson } \\
\text { (2008) }\end{array}$ \\
\hline & Number of patches & $\begin{array}{l}\text { Species richness of } \\
\text { vascular plants }\end{array}$ & $0.61^{* *}$ & Moser et al. (2002) \\
\hline & Edge density & & $0.56^{* *}$ & Moser et al. (2002) \\
\hline & Mean shape index & & $-0.7^{* *}$ & Moser et al. (2002) \\
\hline & Number of patches & $\begin{array}{l}\text { Species richness of } \\
\text { bryophytes }\end{array}$ & $0.6^{* *}$ & Moser et al. (2002) \\
\hline
\end{tabular}


Table 1 - Continued

\begin{tabular}{|c|c|c|c|c|}
\hline Taxa & Landscape metrics & $\begin{array}{l}\text { Dependent vari- } \\
\text { ables }\end{array}$ & Pearson $r$ & References \\
\hline & Edge density & & $0.57^{* *}$ & Moser et al. (2002) \\
\hline & Mean shape index & & $-0.51^{* *}$ & Moser et al. (2002) \\
\hline & $\begin{array}{l}\text { Simpson's diversity } \\
\text { index }\end{array}$ & Native species richness & $0.28^{*}$ & Kumar et al. (2006) \\
\hline & $\begin{array}{l}\text { Interspersion and jux- } \\
\text { taposition index }\end{array}$ & & $0.31^{*}$ & Kumar et al. (2006) \\
\hline & Patch richness density & & $0.35^{*}$ & Kumar et al. (2006) \\
\hline & $\begin{array}{l}\text { Simpson's diversity } \\
\text { index }\end{array}$ & $\begin{array}{l}\text { Non-native species } \\
\text { richness }\end{array}$ & $0.43^{*}$ & Kumar et al. (2006) \\
\hline & $\begin{array}{l}\text { Interspersion and jux- } \\
\text { taposition index }\end{array}$ & & $0.29 *$ & Kumar et al. (2006) \\
\hline & Patch richness density & & $0.4^{*}$ & Kumar et al. (2006) \\
\hline
\end{tabular}

\subsection{Estimating water quality}

Landscape structure is one of the most important factors influencing nutrient and organic matter runoff in watersheds (Turner et al., 2003; Wickham et al., 2003; Uuemaa et al., 2007). Therefore there is increasing demand for indicators and methods that make it possible to evaluate the landscape factors influencing water quality in freshwater management (Griffith, 2002). Several studies have attempted to determine the relationship between land use/land cover structure and water quality but most studies have largely relied on compositional landscape metrics (Kearns et al., 2005). It is, however, clearly important to understand not only the total area of sources and sinks in the landscape, but also their spatial arrangement relative to flowpaths (Gergel, 2005). The importance of the spatial arrangement of land cover within watersheds on water quality has been studied by Jones et al. (2001); King et al. (2005); Li et al. (2005b); Snyder et al. (2005); Xiao and Ji (2007); Uuemaa et al. (2005, 2007); see Table 2.

The spatial pattern of riparian zones is also an especially powerful landscape indicator for water quality, because the variation in length, width, and gaps of riparian buffers influences their effectiveness as nutrient sinks (Gergel et al., 2002). Weller et al. (1998) developed and analyzed models predicting landscape discharge based on material release by an uphill source area, the spatial distribution of a riparian buffer along a stream, and retention within the buffer, and found average width to be the best predictor of landscape discharge for unretentive buffers. Baker et al. (2006) quantified the effects of riparian buffers on watershed nutrient discharges by using, in addition to traditional fixed-distance measures, mean buffer width, gap frequency, and measures of variation in buffer width using both "unconstrained" metrics and "flow-path" metrics constrained by surface topography.

\subsection{Evaluation of landscape pattern and changes therein}

Land use changes are mostly caused by humans, but also by natural disturbances. For example, Lin et al. (2006) used landscape metrics and spatial autocorrelation to assess how earthquakes and typhoons affect landscape patterns, and found that the disturbances produced variously fragmented patches, interspersed with other patches and isolated from patches of the same type across the entire Chenyulan watershed in Taiwan. Results of fire disturbances studies Keane et al. (1999) and Hudak 
Table 2: Correlation between various landscape metrics and water quality parameters. Significance: ${ }^{*} \mathrm{p}<0.05,{ }^{* *} \mathrm{p}<0.01,{ }^{* * *} \mathrm{p}<0.001,{ }^{* * * *} \mathrm{p}<0.0001$.

\begin{tabular}{|c|c|c|c|}
\hline Landscape metrics & Dependent variables & $\begin{array}{r}\text { Pearson } \mathrm{r} \text { or } \\
\text { Spearman } \rho\end{array}$ & References \\
\hline Cropland (\%) & $\log \left(\mathrm{NO}_{3}-\mathrm{N}\right)$ & $0.67^{*}$ & King et al. (2005) \\
\hline Canal line density & $\begin{array}{l}\text { Soluble reactive phos- } \\
\text { phorus reduction }\end{array}$ & $0.8^{*}$ & Li et al. (2005b) \\
\hline Canal connectivity & & $0.83^{*}$ & Li et al. (2005b) \\
\hline Canal circuity & & $0.85^{*}$ & Li et al. (2005b) \\
\hline Canal line density & Total nitrogen reduction & $0.84^{*}$ & Li et al. (2005b) \\
\hline Canal connectivity & & $0.92 *$ & Li et al. (2005b) \\
\hline Canal circuity & & $0.94^{*}$ & Li et al. (2005b) \\
\hline Edge density (forest) & Conductivity & $-0.34^{*}$ & Xiao and Ji (2007) \\
\hline Patch density & & $0.33^{*}$ & Xiao and Ji (2007) \\
\hline Contagion & & $-0.49 *$ & Xiao and Ji (2007) \\
\hline Edge density (forest) & Total Cd & $-0.53^{*}$ & Xiao and Ji (2007) \\
\hline Edge density (forest) & Total Zn & $-0.49 *$ & Xiao and Ji (2007) \\
\hline Contagion & & $-0.36^{*}$ & Xiao and Ji (2007) \\
\hline Patch density & $\begin{array}{l}\mathrm{BOD}_{7} \text { (biological oxy- } \\
\text { gen demand) }\end{array}$ & $-0.53 *$ & Uuemaa et al. (2005) \\
\hline Edge density & & $-0.47 *$ & Uuemaa et al. (2005) \\
\hline Patch density & $\begin{array}{l}\mathrm{COD}_{\mathrm{KMnO}} \text { (chemical } \\
\text { oxygen demand) }\end{array}$ & $-0.49^{*}$ & Uuemaa et al. (2005) \\
\hline Mean shape index & & $0.66^{*}$ & Uuemaa et al. (2005) \\
\hline Edge density & Total-N & $-0.56^{*}$ & Uuemaa et al. (2005) \\
\hline Mean shape index & & $-0.44^{*}$ & Uuemaa et al. (2005) \\
\hline
\end{tabular}


et al. (2004) found that fire creates more diverse, fragmented and disconnected landscapes, and Kashian et al. (2004) found that large, stand-replacing fires may result in heterogeneous forest landscapes rather than homogenous forests of uniform structure. According to Viedma et al. (2006), on the contrary, fire had made the landscape less fragmented and more continuous.

Teixidó et al. (2007) used landscape metrics to study the spatial patterns of the Antarctic benthos in terms of the succession process after iceberg disturbance, and found the first stages of recovery to have low cover area, low complexity of patch shape, small patch size, low diversity and patches that were poorly interspersed to samples from later stages with higher values of these indices.

Many studies have been done on the mapping of forest cover change. Human influence also causes forest fragmentation that also affects species richness (Fuller, 2001; Cayuela et al., 2006; Echeverría et al., 2007; Altamirano et al., 2007). Twentieth century management activities have significantly influenced the structure of the forest landscape (Wolter and White, 2002; Löfman and Kouki, 2003), and altered spatial patterns of physiognomies, cover types and structural conditions, and vulnerabilities to fire, insect, and pathogen disturbances (Hessburg et al., 2000). Logging is one of the main reasons for forest fragmentation, and although it may change the landscape structure at a small spatial scale and not alter the structure of the entire forest mosaic (Leimgruber et al., 2002), it can be associated with dramatic changes in the structure and composition of the forests (Echeverría et al., 2007). Etheridge et al. (2006) also found, using landscape metrics as an indicator, that clearcuts result in the loss of large patches. Zhang and Guindon (2005) used landscape metrics and cellular automata to analyze human impacts on forest fragmentation, and showed that the observed values of scalar landscape metrics and their interrelationships can only be understood by taking into account the spatial pattern aspects associated with causal human drivers of the deforestation process.

\subsection{Urban landscape pattern, road network}

Urbanization has significantly changed natural landscapes everywhere. Urban growth and fragmentation caused by urban sprawl have been extensively studied (Herold et al., 2002; Ji et al., 2006; Tang et al., 2006; Gonzalez-Abraham et al., 2007). It has been shown that landscape pattern is more fragmented around city centres and along coastlines, where urbanization and human economic activities are more concentrated (Yang and Liu, 2005). There are several possibilities as to how to use landscape metrics to detect spatial patterns caused by urbanization. For example, Seto and Fragkias (2005) calculated and analyzed landscape metrics spatiotemporally across three buffer zones, but another effective approach for analyzing systematically the effects of urbanization on ecosystems is to studying the changes in ecosystem patterns and processes along an urban-to-rural gradient (McDonnell et al., 1997). Studies of landscape pattern change along an urban-to-rural gradient focus on the identification of urban texture - whether urban landscapes have unique "spatial signatures" that are distinguishable from other types of landscapes (Weng, 2007). In many studies only land use changes in space are considered (Luck and Wu, 2002; Hahs and McDonnell, 2006; Conway and Hackworth, 2007), but landscape pattern also changes over time. Spatiotemporal gradient analysis makes it possible to determine how the urban centre has shifted in space and time (Wu et al., 2006; Xie et al., 2006; Weng, 2007).

Another critical issue is fragmentation caused by infrastructure, and many studies have revealed that road corridors in the urban landscape increased habitat fragmentation (Saunders et al., 2002; Zhu et al., 2006; Hawbaker et al., 2006; Jaeger et al., 2007). 


\subsection{Landscape aesthetics}

Human perception and intuition can strongly influence how we measure and interpret landscape pattern (D'Eon and Glenn, 2000). Antrop and Van Eetvelde (2000) also emphasise the importance of holism, and found that summed entropy corresponds most closely to the landscape units defined by visual image interpretation, and can be used as a quantitative characteristic of holistically defined landscape units. (Franco et al., 2003) also found strong explanatory relationship between citizens' scenic beauty estimation and the Shannon's diversity index (Table 3).

Table 3: Correlation between various landscape metrics and parameters characterizing landscape aesthetics. Significance: ${ }^{*} \mathrm{p}<0.05,{ }^{* *} \mathrm{p}<0.01,{ }^{* * *} \mathrm{p}<0.001,{ }^{* * * *} \mathrm{p}<0.0001$.

\begin{tabular}{|c|c|c|c|}
\hline Landscape metrics & Dependent variables & $\begin{array}{l}\text { Pearson r or } \\
\text { Spearman } \rho\end{array}$ & References \\
\hline Shannon's diversity index & Scenic beauty estimation & $0.82 * * * *$ & Franco et al. (2003) \\
\hline Edge density & Scenic beauty estimation & $0.42^{* * *}$ & Palmer (2004) \\
\hline Agricultural and open land & & $0.38^{* * *}$ & Palmer (2004) \\
\hline Recreation & & $0.31^{* *}$ & Palmer (2004) \\
\hline Other urban & & $-0.45^{* * *}$ & Palmer (2004) \\
\hline Waste & & $-0.33^{* *}$ & Palmer (2004) \\
\hline Wetland, open water & & $0.33^{* *}$ & Palmer (2004) \\
\hline Largest patch index & $\begin{array}{l}\text { Neighbourhood satisfaction } \\
(0=\text { not satisfied; } 6=\text { very } \\
\text { satisfied })\end{array}$ & $0.18^{* *}$ & Lee et al. (2008) \\
\hline Patch density & & $-0.13^{*}$ & Lee et al. (2008) \\
\hline Total core area & & $0.21^{* *}$ & Lee et al. (2008) \\
\hline $\begin{array}{l}\text { Mean Euclidean nearest } \\
\text { neighbour distance }\end{array}$ & & $-0.23^{* *}$ & Lee et al. (2008) \\
\hline $\begin{array}{l}\text { Area-weighted mean shape } \\
\text { index }\end{array}$ & & $0.15^{* *}$ & Lee et al. (2008) \\
\hline Mean shape index & & $-0.21^{* *}$ & Lee et al. (2008) \\
\hline Cohesion & & $0.14^{*}$ & Lee et al. (2008) \\
\hline Shannon's diversity index & $\begin{array}{l}\text { Preference scores }(1=\text { least } \\
\text { preferred; } 5=\text { most pre- } \\
\text { ferred })\end{array}$ & $0.58^{* *}$ & $\begin{array}{l}\text { Dramstad et al. } \\
(2006)\end{array}$ \\
\hline No. of land types & & $0.53^{* *}$ & $\begin{array}{l}\text { Dramstad et al. } \\
(2006)\end{array}$ \\
\hline No. of patches & & $0.45^{*}$ & $\begin{array}{l}\text { Dramstad et al. } \\
(2006)\end{array}$ \\
\hline Percent open area & & $-0.45^{*}$ & $\begin{array}{l}\text { Dramstad et al. } \\
\text { (2006) }\end{array}$ \\
\hline
\end{tabular}

Palmer (2004) investigated residents' perceptions of scenic quality in the Cape Cod community of Dennis, Massachusetts over a period of significant landscape change, and used landscape metrics to predict residents' perception of scenic value for each time period. The results indicated that landscape composition metrics were more closely related to scenic value than the configuration

Living Reviews in Landscape Research

http: //www. livingreviews . org/lrlr-2009-1 
metrics (Table 3). Scenic value was most positively related to the relative amount of agricultural and related open lands, and the most intensive urban land uses were negatively associated with scenic value. From configuration metrics only edge density was positively related to scenic value. Lee et al. (2008), however, found that residents' neighbourhood satisfaction was more likely to be high when tree patches in neighbourhood environments were less fragmented, less isolated, and well connected (Table 3). Dramstad et al. (2006) also found that spatial configuration is related to people's landscape preferences, and these may therefore be suitable as indicators for the visual landscape (Table 3).

The embedding of the concept of valuable landscapes in legislation such as the European Landscape Convention (Council of Europe, 2004) has led to the need for an 'objective' assessment of these values and the potential impact of changes to them (Sang et al., 2008). The visual characteristics of a landscape are some of the most widely experienced but also most difficult, and controversial (Walker, 1995), to define. Sang et al. (2008) investigated how well landscape metrics predict the results on preference from the Visulands Pan European Survey (http://www.esac.pt/visulands) and the implications of this for the role of preference metrics and visualisation methods in planning processes such as landscape character assessment. Furthermore, Fry et al. (2009) find that landscape metrics have a strong conceptual base in landscape ecological principles but for the visual aspects of landscapes this conceptual base is often missing and thus hindering progress in the development of indicators. Therefore they proposed hierarchical framework for establishing and strengthening links between theory and indicator application.

\subsection{Management and planning}

Landscape metrics are useful for the application of the concepts of landscape ecology to sustainable landscape planning (Botequilha Leitão and Ahern, 2002) and landscape monitoring (Herzog and Lausch, 1999). Lin et al. (2007) combined a land use change model, landscape metrics and a watershed hydrological model with an analysis of the impacts of future land use scenarios on land use pattern and hydrology for a landscape management plan. Landscape metrics also make it possible to detect potential areas for greenways (Colantonio Venturelli and Galli, 2006; Zhang and Wang, 2006), and assess habitat suitability (Holzkämper et al., 2006; Kim and Pauleit, 2007) for landscape planning and management.

Landscape metrics can be useful for assessing soil erosion on large territories (Li, 2008) and help landscape managers to indicate how well landscapes function to retain, not "leak", vital system resources such as rainwater and soil (Ludwig et al., 2002).

Agricultural activities have major effect on floral and faunal species richness of anthropogenic landscapes. As European Union is providing subsidies to farmers for environmentally friendly agricultural practices, there is an urgent need to assess the effectiveness of these subsides. Wrbka et al. (2008) investigated the agri-environmental measures in a parcel-wise manner and analyzed their effects on landscape values and biodiversity. They found that reduction of agrochemicals showed positive effects on biodiversity of vascular plants in grassland and birds in arable land and targeted measures that directly address threatened species were most effective, but had much less coverage. Wrbka et al. (2008) also concluded that agri-environmental measures are currently not targeted enough to effectively halt biodiversity losses. Therefore we also find that researchers should aim for more specific guidelines to evaluate different management schemes. For example, (Greenhill et al., 2003) determined typical ranges of the metrics in environmentally sustainable localities for an extensive suburban area on the southwest edge of London using multispectral IKONOS-2 imagery. The spatial distributions of the metrics provide new insight into landscape structure, which can be exploited in land use planning and in the construction of empirical spatial planning heuristics for sustainable urban development. If researchers determine the critical values or ranges of the landscape metrics where landscape retains its identity or there is positive effect on biodiversity 
then landscape metrics can be extremely useful indicators for measuring the effectiveness of the management schemes. 


\section{Conclusions}

The landscape metrics is one of the hot topics of modern landscape ecological research. However, there is a decreasing trend since 2005 of the papers published in this particular field in high-quality international scientific journals. It indicates that researchers and also practitioners have begun to use pattern metrics more often, skipping correlating ones and choosing only the most informative metrics that truly indicate some relationships between patterns and processes. Yet new metrics are being developed and this fact indicates that there are still some aspects of landscape pattern that existing metrics do not cover or there are problems with scale, interpretability etc. Nevertheless, one should not underestimate the role of landscape metrics in determining the relations between landscape pattern and process.

The majority of papers using landscape metrics/indices/indexes are dedicated to biodiversity and habitat analysis. Also, many articles analyze the relationship of landscape metrics with the evaluation of landscape pattern and changes therein. On the other hand, there are very few articles related to social aspects and landscape perception and therefore one large potential research field is uncovered. Likewise, a lot of research is needed in order to determine landscape metrics useful for landscape management and planning including specifying significant values and ranges of landscape metrics depending on the planning or management purpose.

\section{Acknowledgements}

This study has been supported by the Ministry of Education and Science of Estonia (grants SF0182534s03 and SF0180127s08) and Estonian Science Foundation grants 6083 and 7527. 


\section{References}

Altamirano, A., Echeverría, C., Lara, A. (2007), "Effect of forest fragmentation on vegetation structure of Legrandia concinna (Myrtaceae) threatened populations in south-central Chile", Revista Chilena de Historia Natural, 80(1): 27-42. 3.5

Antrop, M., Van Eetvelde, V. (2000), "Holistic aspects of suburban landscapes: visual image interpretation and landscape metrics", Landscape and Urban Planning, 50(1-3): 43-58, doi: 10.1016/S0169-2046(00)00079-7. 3.7

Baker, M.E., Weller, D.E., Jordan, T.E. (2006), "Improved methods for quantifying potential nutrient interception by riparian buffers", Landscape Ecology, 21(8): 1327-1345, doi:10.1007/s10980006-0020-0. 3.4

Beckler, A.A., French, B.W., Chandler, L.D. (2004), "Characterization of western corn rootworm (Coleoptera: Chrysomelidae) population dynamics in relation to landscape attributes", Agricultural and Forest Entomology, 6(2): 129-139, doi:10.1111/j.1461-9563.2004.00213.x. 1

Botequilha Leitão, A., Ahern, J. (2002), "Applying landscape ecological concepts and metrics in sustainable landscape planning", Landscape and Urban Planning, 59(2): 65-93, doi: 10.1016/S0169-2046(02)00005-1. 3.2, 3.8

Brownstein, J.S., Skelly, D.K., Holford, T.R., Fish, D. (2005), "Forest fragmentation predicts local scale heterogeneity of Lyme disease risk", Oecologia, 146(3): 469-475, doi:10.1007/s00442-0050251-9. 3.3

Burton, M.L., Samuelson, L.J. (2008), "Influence of urbanization on riparian forest diversity and structure in the Georgia Piedmont, US", Plant Ecology, 195(1): 99-115, doi:10.1007/s11258007-9305-x. 3.3, 1

Buyantuyev, A., Wu, J.G. (2007), "Effects of thematic resolution on landscape pattern analysis", Landscape Ecology, 22(1): 7-13, doi:10.1007/s10980-006-9010-5. 3.2

Cain, D.H., Riitters, K., Orvis, K. (1997), "A multi-scale analysis of landscape statistics", Landscape Ecology, 12(4): 199-212, doi:10.1023/A:1007938619068. 1

Carey, A.B., Horton, S.P., Biswell, B.L. (1992), "Northern Spotted Owls: Influence of Prey Base and Landscape Character", Ecological Monographs, 62(2): 223-250, doi:10.2307/2937094. 3.3

Cayuela, L., Benayas, J.M.R., Echeverría, C. (2006), "Clearance and fragmentation of tropical montane forests in the Highlands of Chiapas, Mexico (1975-2000)", Forest Ecology and Management, 226(1-3): 208-218, doi:10.1016/j.foreco.2006.01.047. 3.5

Chamberlain, M.J., Leopold, B.D., Burger, L.W. (2000), "Characteristics of Roost Sites of Adult Wild Turkey Females", Journal of Wildlife Management, 64(4): 1025-1032. 3.3

Clark, W.R., Schmitz, R.A., Bogenschutz, T.R. (1999), "Site Selection and Nest Success of RingNecked Pheasants as a Function of Location in Iowa Landscapes", Journal of Wildlife Management, 63(3): 976-989. 3.3

Colantonio Venturelli, R., Galli, A. (2006), "Integrated indicators in environmental planning: Methodological considerations and applications", Ecological Indicators, 6(1): 228-237, doi: 10.1016/j.ecolind.2005.08.023. 3.8

Living Reviews in Landscape Research

http://www. livingreviews.org/lrlr-2009-1 
Conway, T., Hackworth, J. (2007), "Urban pattern and land cover variation in the greater Toronto area", Canadian Geographer / Le Géographe canadien, 51(1): 43-57, doi:10.1111/j.15410064.2007.00164.x. 3.6

Council of Europe (2004), "The European Landscape Convention", institutional homepage. URL (cited on 6 March 2009):

http://www.coe.int/t/dg4/cultureheritage/conventions/Landscape/Default_en.asp. 3.7

Cushman, S.A., McGarigal, K., Neel, M.C. (2008), "Parsimony in landscape metrics: Strength, universality, and consistency", Ecological Indicators, 8(5): 691-703, doi: 10.1016/j.ecolind.2007.12.002. 3.2

D'Eon, R.G., Glenn, S.M. (2000), "Perceptions of landscape patterns: Do the numbers count?", Forestry Chronicle, 76(3): 475-480. 3.7

Deutschewitz, K., Lausch, A., Kühn, I., Klotz, S. (2003), "Native and alien plant species richness in relation to spatial heterogeneity on a regional scale in Germany", Global Ecology and Biogeography, 12(4): 299-311, doi:10.1046/j.1466-822X.2003.00025.x. 3.3

Dramstad, W.E., Tveit, M.S., Fjellstad, W.J., Fry, G.L.A. (2006), "Relationships between visual landscape preferences and map-based indicators of landscape structure", Landscape and Urban Planning, 78(4): 465-474, doi:10.1016/j.landurbplan.2005.12.006. 3, 3.7

Echeverría, C., Newton, A.C., Lara, A., Benayas, J.M.R., Coomes, D.A. (2007), "Impacts of forest fragmentation on species composition and forest structure in the temperate landscape of southern Chile", Global Ecology and Biogeography, 16(4): 426-439, doi:10.1111/j.1466-8238.2007.00311.x. 3.5

Etheridge, D.A., MacLean, D.A., Wagner, R.G., Wilson, J.S. (2006), "Effects of Intensive Forest Management on Stand and Landscape Characteristics in Northern New Brunswick, Canada (1945-2027)", Landscape Ecology, 21(4): 509-524, doi:10.1007/s10980-005-2378-9. 3.5

Eyre, T.J., Buck, R.G. (2005), "The regional distribution of large gliding possums in southern Queensland, Australia. I. The yellow-bellied glider (Petaurus australis)", Biological Conservation, 125(1): 65-86, doi:10.1016/j.biocon.2005.03.012. 3.3

Fauth, P.T., Gustafson, E.J., Rabenold, K.N. (2000), "Using landscape metrics to model source habitat for Neotropical migrants in the midwestern U.S.", Landscape Ecology, 15(7): 621-631, doi:10.1023/A:1008179208018. 1

Fearer, T.M., Stauffer, D.F. (2003), "Relationship of Ruffed Grouse (Bonasa umbellus) Home Range Size to Landscape Characteristics", American Midland Naturalist, 150(1): 104-114. 3.3

Fernández, N., Delibes, M., Palomares, F. (2007), "Habitat-related heterogeneity in breeding in a metapopulation of the Iberian lynx", Ecography, 30(3): 431-439, doi:10.1111/j.09067590.2007.05005.x. 1

Finder, R.A., Roseberry, J.L., Woolf, A. (1999), "Site and landscape conditions at white-tailed deer/vehicle collision locations in Illinois", Landscape and Urban Planning, 44(2-3): 77-85, doi: 10.1016/S0169-2046(99)00006-7. 3.3

Foster, J.R., Roseberry, J.L., Woolf, A. (1997), "Factors Influencing Efficiency of White-Tailed Deer Harvest in Illinois", Journal of Wildlife Management, 61(4): 1091-1097. 3.3, 1 
Franco, D., Franco, D., Mannino, I., Zanetto, G. (2003), "The impact of agroforestry networks on scenic beauty estimation: The role of a landscape ecological network on a socio-cultural process", Landscape and Urban Planning, 62(3): 119-138, doi:10.1016/S0169-2046(02)00127-5. 3.7, 3

French, B.W., Beckler, A.A., Chandler, L.D. (2004), "Landscape Features and Spatial Distribution of Adult Northern Corn Rootworm (Coleoptera: Chrysomelidae) in the South Dakota Areawide Management Site", Journal of Economic Entomology, 97(6): 1943-1957. 3.3

Fry, G., Tveit, M.S., Ode, A., Velarde, M.D. (2009), "The ecology of visual landscapes: Exploring the conceptual common ground of visual and ecological landscape indicators", Ecological Indicators, 9(5): 933-947, doi:10.1016/j.ecolind.2008.11.008. 3.7

Fuller, D.O. (2001), "Forest fragmentation in Loudoun County, Virginia, USA evaluated with multitemporal Landsat imagery", Landscape Ecology, 16(7): 627-642, doi:10.1023/A:1013140101134. 3.5

Gaines, K.F., Porter, D.E., Punshon, T., Brisbin Jr, I.L. (2005), "A Spatially Explicit Model of the Wild Hog for Ecological Risk Assessment Activities at the Department of Energy's Savannah River Site", Human and Ecological Risk Assessment, 11(3): 567-589, doi: 10.1080/10807030590949654. 3.3

Gergel, S.E. (2005), "Spatial and non-spatial factors: When do they affect landscape indicators of watershed loading?", Landscape Ecology, 20(2): 177-189, doi:10.1007/s10980-004-2263-y. 3.4

Gergel, S.E., Turner, M.G., Miller, J.R., Melack, J.M., Stanley, E.H. (2002), "Landscape indicators of human impacts to riverine systems", Aquatic Sciences, 64(2): 118-128, doi:10.1007/s00027002-8060-2. 3.4

Gonzalez-Abraham, C.E., Radeloff, V.C., Hammer, R.B., Hawbaker, T.J., Stewart, S.I., Clayton, M.K. (2007), "Building patterns and landscape fragmentation in northern Wisconsin, USA", Landscape Ecology, 22(2): 217-230, doi:10.1007/s10980-006-9016-z. 3.6

Graham, A.J., Danson, F.M., Giraudoux, P., Graig, P.S. (2004), "Ecological epidemiology: landscape metrics and human alveolar echinococossis", Acta Tropica, 91(3): 267-278, doi: 10.1016/j.actatropica.2004.05.005. 3.3

Greenhill, D.R., Ripke, L.T., Hitchman, A.P., Jones, G.A., Wilkinson, G.G. (2003), "Characterization of suburban areas for land use planning using landscape ecological indicators derived from IKONOS-2 multispectral imagery", Transactions on Geoscience and Remote Sensing, 41 (9): 2015-2021, doi:10.1109/TGRS.2003.814629. 3.8

Griffith, J.A. (2002), "Geographic techniques and recent applications of remote sensing to landscape-water quality studies", Water, Air, \&f Soil Pollution, 138(1-4): 181-197, doi: 10.1023/A:1015546915924. 3.4

Grilli, M.P. (2008), "An area-wide model approach for the management of a disease vector planthopper in an extensive agricultural system", Ecological Modelling, 213(3-4): 308-318, doi: 10.1016/j.ecolmodel.2007.12.004. 1

Gustafson, E.J. (1998), "Quantifying Landscape Spatial Pattern: What Is the State of the Art?", Ecosystems, 1(2): 143-156, doi:10.1007/s100219900011. 1

Guthery, F.S., Green, M.C., Masters, R.E., DeMaso, S.J., Wilson, H.M., Steubing, F.B. (2001), "Land Cover and Bobwhite Abundance on Oklahoma Farms and Ranches", Journal of Wildlife Management, 65(4): 838-849. 3.3

Living Reviews in Landscape Research

http://www . livingreviews . org/lrlr-2009-1 
Hahs, A.K., McDonnell, M.J. (2006), "Selecting independent measures to quantify Melbourne's urban-rural gradient", Landscape and Urban Planning, 78(4): 435-448, doi: 10.1016/j.landurbplan.2005.12.005. 3.6

Haines-Young, R., Chopping, M. (1996), "Quantifying landscape structure: a review of landscape indices and their application to forested landscapes", Progress in Physical Geography, 20(4): 418-445, doi:10.1177/030913339602000403. 1

Hale, S.S., Paul, J.F., Heltshe, J.F. (2004), "Watershed landscape indicators of estuarine benthic condition", Estuaries and Coasts, 27(2): 283-295, doi:10.1007/BF02803385. 3.3

Hawbaker, T.J., Radeloff, V.C., Clayton, M.K., Hammer, R.B., Gonzales-Abraham, C.E. (2006), "Road Development, Housing Growth, And Landscape Fragmentation In Northern Wisconsin: 1937-1999", Ecological Applications, 16(3): 1222-1237, doi:10.1890/10510761(2006)016[1222:RDHGAL]2.0.CO;2. 3.6

He, H.S., DeZonia, B.E., Mladenoff, D.J. (2000), "An aggregation index (AI) to quantify spatial patterns of landscapes", Landscape Ecology, 15(7): 591-601, doi:10.1023/A:1008102521322. 3.2

Henner, C.M., Chamberlain, M.J., Leopold, B.D., Burger Jr, L.W. (2004), "A Multi-Resolution Assessment of Raccoon Den Selection", Journal of Wildlife Management, 68(1): 179-187, doi: 10.2193/0022-541X(2004)068[0179:AMAORD]2.0.CO;2. 3.3

Hernández-Stefanoni, J.L., Dupuy, J.M. (2008), "Effects of landscape patterns on species density and abundance of trees in a tropical subdeciduous forest of the Yucatan Peninsula", Forest Ecology and Management, 255(11): 3797-3805, doi:10.1016/j.foreco.2008.03.019. 3.3

Herold, M., Scepan, J., Clarke, K.C. (2002), "The use of remote sensing and landscape metrics to describe structures and changes in urban land uses", Environment and Planning A, 34(8): 1443-1458, doi:10.1068/a3496. 3.6

Herzog, F., Lausch, A. (1999), "Prospects and limitations of the application of landscape metrics for landscape monitoring", in Heterogeneity in landscape ecology: Pattern and scale, (Eds.) Maudsley, M., Marshall, J., Proceedings of the 8th Annual Conference of the International Association of Landscape Ecology, Bristol, England, September 06-08, 1999, pp. 41-50, Aberdeen, Scotland (IALE (UK)). 3.8

Hessburg, P.F., Smith, B.G., Salter, R.B., Ottmar, R.D., Alvarado, E. (2000), "Recent changes (1930s - 1990s) in spatial patterns of interior northwest forests, USA", Forest Ecology and Management, 136(1-3): 53-83, doi:10.1016/S0378-1127(99)00263-7. 3.5

Holzkämper, A., Lausch, A., Seppelt, R. (2006), "Optimizing landscape configuratlion to enhance habitat suitability for species with contrasting habitat requirements", Ecological Modelling, 198 (3-4): 277-292, doi:10.1016/j.ecolmodel.2006.05.001. 3.8

Honnay, O., Piessens, K., Van Landuyt, W., Hermy, M., Gulinck, H. (2003), "Satellite based land use and landscape complexity indices as predictors for regional plant species diversity", Landscape and Urban Planning, 63(4): 241-250, doi:10.1016/S0169-2046(02)00194-9. 3.3

Huang, C., Geiger, E.L., Kupfer, J.A. (2006), "Sensitivity of landscape metrics to classification scheme", International Journal of Remote Sensing, 27(14): 2927-2948, doi: 10.1080/01431160600554330. 3.2

Hudak, A.T., Fairbanks, D.H.K., Brockett, B.H. (2004), "Trends in fire patterns in a southern African savanna under alternative land use practices", Agriculture, Ecosystems 83 Environment, 101(2-3): 307-325, doi:10.1016/j.agee.2003.09.010. 3.5 
Iampietro, P.J., Kvitek, R.G., Morris, E. (2005), "Recent advances in automated genus-specific marine habitat mapping enabled by high-resolution multibeam bathymetry", Marine Technology Society Journal, 39(3): 83-93. 1

Jackson, V.L., Laack, L.L., Zimmerman, E.G. (2005), "Landscape Metrics Associated with Habitat Use by Ocelots in South Texas", Journal of Wildlife Management, 69(2): 733-738, doi: 10.2193/0022-541X(2005)069[0733:LMAWHU]2.0.CO;2. 3.3

Jaeger, J.A.G. (2000), "Landscape division, splitting index, and effective mesh size: new measures of landscape fragmentation", Landscape Ecology, 15(2): 115-130, doi:10.1023/A:1008129329289. 3.2

Jaeger, J.A.G., Schwarz-von Raumer, H.-G., Esswein, H., Müller, M., Schmidt-Lüttmann, M. (2007), "Time Series of Landscape Fragmentation Caused by Transportation Infrastructure and Urban Development: a Case Study from Baden-Württemberg, Germany", Ecology and Society, 12(1), 22. URL (cited on 26 February 2009):

http://www.ecologyandsociety.org/vol12/iss1/art22/. 3.6

Ji, W., Ma, J., Twibell, R.W., Underhill, K. (2006), "Characterizing urban sprawl using multi-stage remote sensing images and landscape metrics", Computers, Environment and Urban Systems, 30(6): 861-879, doi:10.1016/j.compenvurbsys.2005.09.002. 3.6

Jones, K.B., Neale, A.C., Nash, M.S., Van Remortel, R.D., Wickham, J.D., Riitters, K.H., O’Neill, R.V. (2001), "Predicting nutrient and sediment loadings to streams from landscape metrics: A multiple watershed study from the United States Mid-Atlantic Region", Landscape Ecology, 16 (4): 301-312, doi:10.1023/A:1011175013278. 3.4

Kashian, D.M., Tinker, D.B., Turner, M.G., Scarpace, F.L. (2004), "Spatial heterogeneity of lodgepole pine sapling densities following the 1988 fires in Yellowstone National Park, Wyoming, USA", Canadian Journal of Forest Research, 34(11): 2263-2276, doi:10.1139/x04-107. 3.5

Keane, R.E., Morgan, P., White, J.D. (1999), "Temporal patterns of ecosystem processes on simulated landscapes in Glacier National Park, Montana, USA", Landscape Ecology, 14(3): 311-329, doi:10.1023/A:1008011916649. 3.5

Kearns, F.R., Kelly, N.M., Carter, J.L., Resh, V.H. (2005), "A method for the use of landscape metrics in freshwater research and management", Landscape Ecology, 20(1): 113-125, doi:10.1007/s10980-004-2261-0. 3.4

Kie, J.G., Bowyer, R.T., Nicholson, M.C., Boroski, B.B., Loft, E.R. (2002), "Landscape heterogeneity at differing scales: Effects on spatial distribution of mule deer", Ecology, 83(2): 530-544, doi:10.1890/0012-9658(2002)083[0530:LHADSE]2.0.CO;2. 3.3

Kim, K.H., Pauleit, S. (2007), "Landscape character, biodiversity and land use planning: The case of Kwangju City Region, South Korea", Land Use Policy, 24(1): 264-274, doi: 10.1016/j.landusepol.2005.12.001. 3.8

Kindall, J.L., Van Manen, F.T. (2007), "Identifying Habitat Linkages for American Black Bears in North Carolina, USA", Journal of Wildlife Management, 71(2): 487-495, doi:10.2193/2005-709. 3.3

King, R.S., Baker, M.E., Whigham, D.F., Weller, D.E., Jordan, T.E., Kazyak, P.F., Hurd, M.K. (2005), "Spatial Considerations for Linking Watershed Land Cover to Ecological Indicators in Streams", Ecological Applications, 15(1): 137-153, doi:10.1890/04-0481. 3.4, 2

Living Reviews in Landscape Research

http://www. livingreviews . org/lrlr-2009-1 
Knutson, M.G., Sauer, J.R., Olsen, D.A., Mossman, M.J., Hemesath, L.M., Lannoo, M.J. (1999), "Effects of Landscape Composition and Wetland Fragmentation on Frog and Toad Abundance and Species Richness in Iowa and Wisconsin, USA", Conservation Biology, 13(6): 1437-1446, doi:10.1046/j.1523-1739.1999.98445.x. 3.3

Kumar, S., Stohlgren, T.J., Chong, G.W. (2006), "Spatial heterogeneity influences native and nonnative plant species richness", Ecology, 87(12): 3186-3199, doi:10.1890/00129658(2006)87[3186:SHINAN]2.0.CO;2. 3.3, 1

Langford, W.T., Gergel, S.E., Dietterich, T.G., Cohen, W. (2006), "Map Misclassification Can Cause Large Errors in Landscape Pattern Indices: Examples from Habitat Fragmentation", Ecosystems, 9(3): 474-488, doi:10.1007/s10021-005-0119-1. 3.2

Lee, S.-W., Ellis, C.D., Kweon, B.-S., Hong, S.-K. (2008), "Relationship between landscape structure and neighborhood satisfaction in urbanized areas", Landscape and Urban Planning, 85(1): 60-70, doi:10.1016/j.landurbplan.2007.09.013. 3, 3.7

Leimgruber, P., McShea, W.J., Schnell, G.D. (2002), "Effects of Scale and Logging on Landscape Structure in a Forest Mosaic", Environmental Monitoring and Assessment, 74(2): 141-166, doi:10.1023/A:1013881319390. 3.5

Li, H.B., Wu, J.G. (2004), "Use and misuse of landscape indices", Landscape Ecology, 19(4): 389-399, doi:10.1023/B:LAND.0000030441.15628.d6. 1

Li, X.Z., He, H.S., Bu, R.C., Wen, Q.C., Chang, Y., Hu, Y.M., Li, Y.H. (2005a), "The adequacy of different landscape metrics for various landscape patterns", Pattern Recognition, 38(12): 26262638, doi:10.1016/j.patcog.2005.05.009. 3.2

Li, X.Z., Jongman, R.H.G., Hu, Y.M., Bu, R.C., Harms, B., Bregt, A.K., He, H.S. (2005b), "Relationship between landscape structure metrics and wetland nutrient retention function: A case study of Liaohe Delta, China", Ecological Indicators, 5(4): 339-349, doi: 10.1016/j.ecolind.2005.03.007. 3.4, 2

Li, Y.C. (2008), "Land cover dynamic changes in northern China: 1989-2003", Journal of Geographical Sciences, 18(1): 85-94, doi:10.1007/s11442-008-0085-6. 3.8

Limpert, D.L., Birch, D.L., Scott, M.S., Andre, M., Gillam, E. (2007), "Tree Selection and Landscape Analysis of Eastern Red Bat Day Roosts", Journal of Wildlife Management, 71(2): 478486, doi:10.2193/2005-642. 3.3

Lin, Y.P., Chang, T.K., Wu, C.F., Chiang, T.C., Lin, S.H. (2006), "Assessing Impacts of Typhoons and the Chi-Chi Earthquake on Chenyulan Watershed Landscape Pattern in Central Taiwan Using Landscape Metrics", Environmental Management, 38(1): 108-125, doi:10.1007/s00267005-0077-6. 3.5

Lin, Y.P., Hong, N.M., Wu, P.J., Wu, C.F., Verburg, P.H. (2007), "Impacts of land use change scenarios on hydrology and land use patterns in the Wu-Tu watershed in Northern Taiwan", Landscape and Urban Planning, 80(1-2): 111-126, doi:10.1016/j.landurbplan.2006.06.007. 3.8

Liu, Y.B., Nishiyama, S., Kusaka, T. (2003), "Examining Landscape Dynamics at a Watershed Scale Using Landsat TM Imagery for Detection of Wintering Hooded Crane Decline in Yashiro, Japan", Environmental Management, 31(3): 365-376, doi:10.1007/s00267-002-2785-5. 1

Löfman, S., Kouki, J. (2003), "Scale and dynamics of a transforming forest landscape", Forest Ecology and Management, 175(1-3): 247-252, doi:10.1016/S0378-1127(02)00133-0. 3.5 
Luck, M., Wu, J.G. (2002), "A gradient analysis of urban landscape pattern: a case study from the Phoenix metropolitan region, Arizona, USA", Landscape Ecology, 17(4): 327-339, doi: 10.1023/A:1020512723753. 3.6

Ludwig, J.A., Eager, R.W., Bastin, G.N., Chewings, V.H., Liedloff, A.C. (2002), "A leakiness index for assessing landscape function using remote sensing", Landscape Ecology, 17(2): 157171, doi:10.1023/A:1016579010499. 3.8

Maier, J.A.K., Ver Hoef, J.M., McGuire, A.D., Bowyer, R.T., Saperstein, L., Maier, H.A. (2005), "Distribution and density of moose in relation to landscape characteristics: effects of scale", Canadian Journal of Forest Research, 35(9): 2233-2243, doi:10.1139/x05-123. 3.3

Mander, Ü., Müller, F., Wrbka, T. (2005), "Functional and structural landscape indicators: Upscaling and downscaling problems", Ecological Indicators, 5(4): 267-272, doi: 10.1016/j.ecolind.2005.04.001. 1

McAlpine, C.A., Eyre, T.J. (2002), "Testing landscape metrics as indicators of habitat loss and fragmentation in continuous eucalypt forests (Queensland, Australia)", Landscape Ecology, 17 (8): 711-728, doi:10.1023/A:1022902907827. 3.3, 1

McDonnell, M.J., Pickett, S.T.A., Groffman, P., Bohlen, P., Pouyat, R.V., Zipperer, W.C., Parmelee, R.W., Carreiro, M.M., Medley, K. (1997), "Ecosystem processes along an urbanto-rural gradient", Urban Ecosystems, 1(1): 21-36, doi:10.1023/A:1014359024275. 3.6

McGarigal, K., Marks, B.J. (1995), "FRAGSTATS: Spatial Pattern Analysis Program for Quantifying Landscape Structure", General Technical Reports, PNW-GTR-351, Portland (USDA Forest Service, Pacific Northwest Research Station). Related online version (cited on 24 February 2009): http://www.fs.fed.us/pnw/pubs/gtr_351.pdf. 1

McGarigal, K., Cushman, S.A., Neel, M.C., Ene, E. (2002), "FRAGSTATS: Spatial Pattern Analysis Program for Categorical Maps", project homepage, University of Massachusetts, Amherst. URL (cited on 24 February 2009):

http://www.umass.edu/landeco/research/fragstats/fragstats.html. 1, 3.2

Michalski, F., Peres, C.A. (2005), "Anthropogenic determinants of primate and carnivore local extinctions in a fragmented forest landscape of southern Amazonia", Biological Conservation, 124(3): 383-396, doi:10.1016/j.biocon.2005.01.045. 1

Miller, D.A., Conner, L.M. (2007), "Habitat Selection of Female Turkeys in a Managed Pine Landscape in Mississippi", Journal of Wildlife Management, 71(3): 744-751, doi:10.2193/2005738. 3.3

Mladenoff, D.J., Sickley, T.A., Haight, R.G., Wydeven, A.P. (1995), "A Regional Landscape Analysis and Prediction of Favorable Gray Wolf Habitat in the Northern Great Lakes Region", Conservation Biology, 9(2): 279-294, doi:10.1046/j.1523-1739.1995.9020279.x. 3.3

Moser, D., Zechmeister, H.G., Plutzar, C., Sauberer, N., Wrbka, T., Grabherr, G. (2002), "Landscape patch shape complexity as an effective measure for plant species richness in rural landscapes", Landscape Ecology, 17(7): 657-669, doi:10.1023/A:1021513729205. 3.3, 1

Neel, M.C., McGarigal, K., Cushman, S.A. (2004), "Behavior of class-level landscape metrics across gradients of class aggregation and area", Landscape Ecology, 19(4): 435-455, doi: 10.1023/B:LAND.0000030521.19856.cb. 3.2 
Openshaw, S., Taylor, P.J. (1981), "The modifiable areal unit problem", in Quantitative Geography: A British View, (Eds.) Wrigley, N., Bennett, R.J., pp. 60-70, London (Routledge and Kegan). 3.2

Overgaard, H.J., Ekbom, B., Suwonkerd, W., Takagi, M. (2003), "Effect of landscape structure on anopheline mosquito density and diversity in northern Thailand: Implications for malaria transmission and control", Landscape Ecology, 18(6): 605-619, doi:10.1023/A:1026074910038. $3.3,1$

Palmer, J.F. (2004), "Using spatial metrics to predict scenic perception in a changing landscape: Dennis, Massachusetts", Landscape and Urban Planning, 69(2-3): 201-218, doi: 10.1016/j.landurbplan.2003.08.010. 3, 3.7

Pellet, J., Hoehn, S., Perrin, N. (2004), "Multiscale determinants of tree frog (Hyla arborea L.) calling ponds in western Switzerland", Biodiversity and Conservation, 13(12): 2227-2235, doi: 10.1023/B:BIOC.0000047904.75245.1f. 3.3, 1

Perkins, M.W., Conner, L.M. (2003), "Bachman's Sparrow Habitat in the Lower Flint River Basin, Georgia", in Proceedings of the 57th Annual Conference of the Southeastern Association of Fish and Wildlife Agencies, (Eds.) Eversole, A.G., Wong, K.C., Chamberlain, M., Galvez, J.I., October 11-15, 2003, Mobile, Alabama, pp. 235-242, Tallahassee (SEAFWA). Related online version (cited on 3 March 2009):

http: //24.73.102.130/view . asp?id=4808. 3.3

Plante, M., Lowell, K., Potvin, F., Boots, B., Fortin, M.-J. (2004), "Studying deer habitat on Anticosti Island, Québec: relating animal occurrences and forest map information", Ecological Modelling, 174(4): 387-399, doi:10.1016/j.ecolmodel.2003.09.035. 3.3, 1

Radeloff, V.C., Mladenoff, D.J., Boyce, M.S. (2000), "The changing relation of landscape patterns and jack pine budworm populations during an outbreak", Oikos, 90(3): 417-430, doi: 10.1034/j.1600-0706.2000.900301.x. 3.3, 1

Ribe, R., Morganti, R., Hulse, D., Shull, R. (1998), "A management driven investigation of landscape patterns of northern spotted owl nesting territories in the high Cascades of Oregon", Landscape Ecology, 13(1): 1-13, doi:10.1023/A:1007976931500. 3.3

Riitters, K.H., O’Neill, R.V., Hunsaker, C.T., Wickham, J.D., Yankee, D.H., Timmins, S.P., Jones, K.B., Jackson, B.L. (1995), "A factor analysis of landscape pattern and structure metrics", Landscape Ecology, 10(1): 23-39, doi:10.1007/BF00158551. 1, 3.2

Roschewitz, I., Hücker, M., Tscharntke, T., Thies, C. (2005), "The influence of landscape context and farming practices on parasitism of cereal aphids", Agriculture, Ecosystems 65 Environment, 108(3): 218-227, doi:10.1016/j.agee.2005.02.005. 3.3

Sang, N., Ode, A., Miller, D. (2008), "Landscape metrics and visual topology in the analysis of landscape preference", Environment and Planning B: Planning and Design, 35(3): 504-520, doi:10.1068/b33049. 3.7

Saunders, S.C., Mislivets, M.R., Chen, J.Q., Cleland, D.T. (2002), "Effects of roads on landscape structure within nested ecological units of the Northern Great Lakes Region, USA", Biological Conservation, 103(2): 209-225, doi:10.1016/S0006-3207(01)00130-6. 3.6

Schils, T. (2006), "The tripartite biogeographical index: a new tool for quantifying spatiotemporal differences in distribution patterns", Journal of Biogeography, 33(4): 560-572, doi: 10.1111/j.1365-2699.2005.01416.x. 1 
Schindler, S., Poirazidis, K., Wrbka, T. (2008), "Towards a core set of landscape metrics for biodiversity assessments: A case study from Dadia National Park, Greece", Ecological Indicators, 8(5): 502-514, doi:10.1016/j.ecolind.2007.06.001. 3.2

Seto, K.C., Fragkias, M. (2005), "Quantifying Spatiotemporal Patterns of Urban Land-use Change in Four Cities of China with Time Series Landscape Metrics", Landscape Ecology, 20(7): 871888, doi:10.1007/s10980-005-5238-8. 3.6

Snyder, M.N., Goetz, S.J., Wright, R.K. (2005), "Stream health rankings predicted by satellite derived land cover metrics", Journal of the American Water Resources Association, 41(3): 659677, doi:10.1111/j.1752-1688.2005.tb03762.x. 3.4

Stephens, S.E., Rotella, J.J., Lindberg, M.S., Taper, M.L., Ringelman, J.K. (2005), "Duck Nest Survival in the Missouri Coteau of North Dakota: Landscape Effects at Multiple Spatial Scales", Ecological Applications, 15(6): 2137-2149, doi:10.1890/04-1162. 3.3

Stubblefield, C.H., Vierling, K.T., Rumble, M.A. (2006), "Landscape-Scale Attributes of Elk Centers of Activity in the Central Black Hills of South Dakota", Journal of Wildlife Management, 70(4): 1060-1069, doi:10.2193/0022-541X(2006)70[1060:LAOECO]2.0.CO;2. 3.3

Tang, J.M., Wang, L., Yao, Z.J. (2006), "Analyzing Urban Sprawl Spatial Fragmentation Using Multi-temporal Satellite Images", GIScience \&f Remote Sensing, 43(3): 218-232, doi: 10.2747/1548-1603.43.3.218. 3.6

Teixidó, N., Garrabou, J., Gutt, J., Arntz, W.E. (2007), "Iceberg Disturbance and Successional Spatial Patterns: The Case of the Shelf Antarctic Benthic Communities", Ecosystems, 10(1): 143-158, doi:10.1007/s10021-006-9012-9. 3.5

Turner, M.G. (1989), "Landscape Ecology: The Effect of Pattern on Process", Annual Review of Ecology and Systematics, 20: 171-197, doi:10.1146/annurev.es.20.110189.001131. 3.3

Turner, M.G. (1990), "Spatial and temporal analysis of landscape patterns", Landscape Ecology, 4(1): 21-30, doi:10.1007/BF02573948. 1

Turner, R.E., Rabalais, N.N., Justic, D., Dortch, Q. (2003), "Global patterns of dissolved N, P and Si in large rivers", Biogeochemistry, 64(3): 297-317, doi:10.1023/A:1024960007569. 1, 3.4

Twedt, D.J., Wilson, R.R., Keister, A.S. (2007), "Spatial Models of Northern Bobwhite Populations for Conservation Planning", Journal of Wildlife Management, 71(6): 1808-1818, doi: 10.2193/2006-567. 3.3

Uuemaa, E., Roosaare, J., Mander, Ü. (2005), "Scale dependence of landscape metrics and their indicatory value for nutrient and organic matter losses from catchments", Ecological Indicators, 5(4): 350-369, doi:10.1016/j.ecolind.2005.03.009. 3.2, 3.4, 2

Uuemaa, E., Roosaare, J., Mander, Ü. (2007), "Landscape metrics as indicators of river water quality at catchment scale", Nordic Hydrology, 38(2): 125-138, doi:10.2166/nh.2007.002. 3.4

Viedma, O., Moreno, J.M., Rieiro, I. (2006), "Interactions between land use/land cover change, forest fires and landscape structure in Sierra de Gredos (Central Spain)", Environmental Conservation, 33(3): 212-222, doi:10.1017/S0376892906003122. 3.5

Vivoni, E.R., Teles, V., Ivanov, V.Y., Bras, R.L., Entekhabi, D. (2005), "Embedding landscape processes into triangulated terrain models", International Journal of Geographical Information Science, 19(4): 429-457, doi:10.1080/13658810512331325111. 1

Living Reviews in Landscape Research

http://www. livingreviews.org/lrlr-2009-1 
Walker, G. (1995), "Renewable energy and the public", Land Use Policy, 12(1): 49-59, doi: 10.1016/0264-8377(95)90074-C. 3.7

Weller, D.E., Jordan, T.E., Correll, D.L. (1998), "Heuristic Models for Material Discharge from Landscapes with Riparian Buffers", Ecological Applications, 8(4): 1156-1169, doi:10.1890/10510761(1998)008[1156:HMFMDF]2.0.CO;2. 3.4

Weng, Y.-C. (2007), "Spatiotemporal changes of landscape pattern in response to urbanization", Landscape and Urban Planning, 81(4): 341-353, doi:10.1016/j.landurbplan.2007.01.009. 3.6

Wickham, J.D., Riitters, K.H. (1995), "Sensitivity of landscape metrics to pixel size", International Journal of Remote Sensing, 16(18): 3585-3594, doi:10.1080/01431169508954647. 1, 3.2

Wickham, J.D., O'Neill, R.V., Riitters, K.H., Wade, T.G., Jones, K.B. (1997), "Sensitivity of Selected Landscape Pattern Metrics to Land-Cover Misclassification and Differences in LandCover Composition", Photogrammetric Engineering \&3 Remote Sensing, 63(4): 397-402. 3.2

Wickham, J.D., Wade, T.G., Riitters, K.H., O'Neill, R.V., Smith, J.H., Smith, E.R., Jones, K.B., Neale, A.C. (2003), "Upstream-to-downstream changes in nutrient export risk", Landscape Ecology, 18(2): 193-206, doi:10.1023/A:1024490121893. 3.4

Wigley, T.B., Sweeney, S.W., Sweeney, J.R. (1999), "Habitat Attributes and Reproduction of Red-Cockaded Woodpeckers in Intensively Managed Forests", Wildlife Society Bulletin, 27(3): 801-809. 3.3

Williamson, M. (1999), "Invasions", Ecography, 22(1): 5-12, doi:10.1111/j.16000587.1999.tb00449.x. 3.3

Wolter, P.T., White, M.A. (2002), "Recent forest cover type transitions and landscape structural changes in northeast Minnesota, USA", Landscape Ecology, 17(2): 133-155, doi: 10.1023/A:1016522509857. 3.5

Wrbka, T., Schindler, S., Pollheimer, M., Schmitzberger, I., Peterseil, J. (2008), "Impact of the Austrian Agri-environmental scheme on diversity of landscapes, plants and birds", Community Ecology, 9(2): 217-227, doi:10.1556/ComEc.9.2008.2.11. 3.8

Wu, J.G. (2004), "Effects of changing scale on landscape pattern analysis: scaling relations", Landscape Ecology, 19(2): 125-138, doi:10.1023/B:LAND.0000021711.40074.ae. 3.2

Wu, J.G., Shen, W.J., Sun, W.Z., Tueller, P.T. (2002), "Empirical patterns of the effects of changing scale on landscape metrics", Landscape Ecology, 17(8): 761-782, doi: 10.1023/A:1022995922992. 3.2

Wu, Q., Hu, D., Wang, R.S., Li, H.Q., He, Y., Wang, M., Wang, B.H. (2006), "A GIS-based moving window analysis of landscape pattern in the Beijing metropolitan area, China", International Journal of Sustainable Development and World Ecology, 13(5): 419-434. 3.6

Xiao, H.G., Ji, W. (2007), "Relating landscape characteristics to non-point source pollution in mine waste-located watersheds using geospatial techniques", Journal of Environmental Management, 82(1): 111-119, doi:10.1016/j.jenvman.2005.12.009. 3.4, 2

Xie, Y.C., Yu, M., Bai, Y.F., Xing, X.R. (2006), "Ecological analysis of an emerging urban landscape pattern-desakota: a case study in Suzhou, China", Landscape Ecology, 21(8): 1297-1309, doi:10.1007/s10980-006-0024-9. 3.6 
Yang, K., Wang, X.H., Yang, G.J., Wu, X.H., Qi, Y.L., Li, H.J., Zhou, X.N. (2008), "An integrated approach to identify distribution of Oncomelania hupensis, the intermediate host of Schistosoma japonicum, in a mountainous region in China", International Journal for Parasitology, 38(8-9): 1007-1016, doi:10.1016/j.ijpara.2007.12.007. 3.3

Yang, X.J., Liu, Z. (2005), "Quantifying landscape pattern and its change in an estuarine watershed using satellite imagery and landscape metrics", International Journal of Remote Sensing, 26(23): 5297-5323, doi:10.1080/01431160500219273. 3.6

Zhang, L.Q., Wang, H.Z. (2006), "Planning an ecological network of Xiamen Island (China) using landscape metrics and network analysis", Landscape and Urban Planning, 78(4): 449-456, doi: 10.1016/j.landurbplan.2005.12.004. 3.8

Zhang, Y., Guindon, B. (2005), "Landscape analysis of human impacts on forest fragmentation in the Great Lakes region", Canadian Journal of Remote Sensing, 31(2): 153-166. 3.5

Zhu, M., Xu, J.G., Jiang, N., Li, J.L., Fan, Y.M. (2006), "Impacts of road corridors on urban landscape pattern: a gradient analysis with changing grain size in Shanghai, China", Landscape Ecology, 21(5): 723-734, doi:10.1007/s10980-005-5323-z. 3.6 